\title{
Penerapan Metode Diskusi Berbasis E-Learning dengan Penggunaan Aplikasi Edmodo, Zoom Cloud Meeting dan Quizizz untuk Meningkatkan Hasil Belajar Mahasiswa Materi Sistem Pencernaan pada Program Studi Keperawatan UIN Alauddin Makassar
}

\author{
Nurul Khusnul Khotimah ${ }^{1^{*}}$, Maria Ulfa Ashar ${ }^{2}$, Nurhidayah ${ }^{3}$ \\ ${ }^{1,2,3}$ UIN Alauddin Makassar, Makassar, Indonesia \\ *Coresponding Author : nurul.khusnul@uin-alauddin.ac.id \\ Dikirim: 07-06-2021 ; Direvisi: 08-06-2021 ; Diterima: 09-06-2021
}

\begin{abstract}
Abstrak: Metode diskusi merupakan upaya membahas suatu topik atau materi perkuliahan dengan cara bertukar pendapat dan informasi yang dilakukan oleh dua orang atau lebih. Dalam konteks penelitian ini, metode pembelajaran berbasis e-learning menggunakan aplikasi Edmodo, Zoom Cloud Meeting dan Quizizz.. Penelitian tindakan kelas (PTK) merupakan kegiatan penelitian yang dilakukan terhadap sejumlah mata pelajaran yang menjadi sasaran yaitu siswa, bertujuan untuk memperbaiki situasi pembelajaran di kelas agar kualitas pembelajaran meningkat. Penelitian Tindakan Kelas ini dilaksanakan untuk meningkatkan aktivitas belajar dan hasil belajar dengan penerapan Metode Diskusi Berbasis E-learning menggunakan aplikasi Edmodo, materi Zoom Cloud Meeting dan Quizizz digestion system pada Program Studi Ilmu Keperawatan UIN Alauddin Makassar Semester 4 Akademik. Tahun 2020/2021. Penelitian ini merupakan penelitian tindakan kelas yang diimplementasikan sebagai strategi pemecahan masalah. Dalam penelitian tindakan ini dibagi menjadi 3 tahapan yaitu perencanaan (planning), tindakan (action) dan observasi (observasi). Ketuntasan hasil belajar pada pra siklus 36 siswa atau $(57,14 \%)$ pada siklus I mencapai 48 siswa atau $(76,19 \%)$ mengalami peningkatan sebanyak 12 siswa atau $(19,05 \%)$, dan tingkat ketuntasan belajar siswa menurun. sebanyak 12 siswa $(19,05 \%)$ dari jumlah siswa yang berjumlah 63 siswa. Pada siklus II tingkat ketuntasan mencapai 63 siswa atau (100\%) terjadi peningkatan hasil belajar siswa sebanyak 15 siswa atau $(20,58 \%)$ dan tingkat ketuntasan siswa menurun sebanyak 7 siswa atau (23,81\%). Penerapan metode diskusi berbasis E-learning dengan menggunakan aplikasi Zoom Cloud Meeting, Edmodo dan Quizizz dapat meningkatkan hasil belajar mahasiswa pada materi sistem pencernaan di Program Studi Ilmu Keperawatan UIN Alauddin Makassar Semester 4 Tahun Ajaran 2020/2021.
\end{abstract}

Kata Kunci: Metode Diskusi Berbasis E-learning; Aplikasi Edmodo; Zoom Cloud Meeting; Kuis; Kegiatan Mahasiswa Program Studi Keperawatan

Abstract: Discussion Methods is an effort to discuss a learning topic or material by exchanging opinions and information between two or more people. In the recent study, Elearning-based method utilized Edmodo, Zoom Cloud Meeting, and Quizizz platforms. Classroom Action Research (CAR) is a research activity carried out on a number of subjects that are targeted, namely students, aiming to improve the learning situation in the classroom so that learning quality increases. This Classroom Action Research was carried out to improve learning activities and learning outcomes with the application of E-learning-based Discussion Methods using the Edmodo application, Zoom Cloud Meeting and Quizizz digestion system material in the Nursing Study Program at UIN Alauddin Makassar Semester 4 Academic Year 2020/2021. This research is a form of classroom action research which is implemented as a problem solving strategy. In action research it is divided into 3 
stages, namely planning (planning), action (action) and observation (observe). The completeness of learning outcomes in pre-cycle 36 students or $(57.14 \%)$ in the first cycle reached 48 students or $(76.19 \%)$ experienced an increase in 12 students or $(19.05 \%)$, and the level of student learning incompleteness decreased by 12 students $(19.05 \%)$ of the total number of students who are 63 students. In the second cycle the completeness level reached 63 students or (100\%) there was an increase in student learning outcomes by 15 students or $(20.58 \%)$ and the student incomplete rate decreased by 7 students or $(23.81 \%)$. The application of the E-learning-based discussion method using the Zoom Cloud Meeting, Edmodo and Quizizz applications can improve student learning outcomes on digestion system materials in the Nursing Study Program of UIN Alauddin Makassar Semester 4 Academic Year 2020/2021.

Keywords: E-learning-Based Discussion Methods; Edmodo Applications; Zoom Cloud Meeting; Quizizz; Student Activities Nursing Study Program

\section{PENDAHULUAN}

Setelah merebaknya wabah COVID-19, dunia pendidikan mengalami perubahan yang luar biasa khususnya dalam sistem pembelajaran. Pembelajaran secara konvensional tatap muka langsung dengan peserta didik, mahasiswa yang selama bertahun-tahun bahkan berabad-abad telah berjalan, tiba-tiba pada kondisi tertentu dihentikkan sampai batas waktu tertentu pula. Kondisi ini mendorong pelaku pendidikan, termasuk peneliti untuk berupaya, berinovasi agar proses pembelajaran terus berjalan efektif meskipun dalam kondisi tidak melalui tatap muka konvensional. Pembelajaran merupakan suatu sistem yang kompleks yang keberhasilannya dapat dilihat dari dua aspek yaitu aspek produk dan aspek proses. Keberhasilan pembelajaran dilihat dari sisi produk adalah keberhasilan siswa mengenai hasil yang diperoleh dengan mengabaikan proses pembelajaran (Sanjaya, 2011).

Untuk mendapatkan produk pembelajaran, tentu akan diawali dengan proses pembelajaran, atau perkuliahan. Proses melaksanakan proses pembelajaran tidak mengalami banyak kendala ketika bisa bertatap muka langsung dengan mahasiswa di kelas nyata, demikian pula untuk menghasilkan produk pembelajaran, dapat dilakukan penilaian hasil belajar langsung setelah selesai proses atau bersamaan proses pembelajaran.

Dengan merebaknya wabah COVID-19, dimana pelaksanaan pembelajaran, perkuliahan tidak bisa dialksanakan secara tatap muka dan kemudian ditindaklanjuti dengan dikeluarkannya regulasi-regulasi yang secara langsung maupun tidak langsung berdampak pada proses peembelajaran, perkuliahan termasuk di Perguruan Tinggi, khususnya di UIN Alauddin Makassar Program Studi Keperawatan Semester 4 Tahun Akademik 2020/2021. Keputusan Presiden Republik Indonesia Nomor 12 tahun 2020 Tentang Penetapan Bencana Nonalam Penyebaran Corona Virus Disesease 2019 (COVID-19) menyatakan bencana nonalam yang diakibatkan oleh penyebaran Corona Virus Disease 2019 (COVID-19) sebagai bencana nasional. Lebih lanjut dikeluarkanya Maklumat Rektor UIN Alauddin Makassar Nomor Istimewa/P/UN-06/HK.07.7/03/2020 yang berisi antara lain bahwa kepada Seluruh Dosen, Tenaga kependidikan dan Mahasiwa mulai 20 Maret s/d 31 Maret 2020, kampus ditutup sementara. Pada perkembangan selanjutnya khususnya di di UIN 
Alauddin Makassar Program Studi Keperawatan Semester 4 Tahun Akademik 2020/2021 perkuliahan diilaksanakan secara daring (dalam jaringan).

Kondisi tersebut memacu dan mengharuskan peneliti melaksanakan proses pembelajaran daring, karena dosen dituntut untuk segera melaksanakan pembelajaran daring, sesuai dengan SAP (Satuan Acara Perkuliahan) yang telah disusun. Pada pembelajaran pra-sikus, awal pembelajaran daring berbasis e-learning, peneliti memilih satu aplikasi Zoom Cloud Meeting.

Hasil refleksi awal pembelajaran daring berbasis e-learning pra siklus menunjukkan aktivitas belajar mahasiswa rendah dan berdampak pada rendahnya hasil belajar mahasiswa di UIN Alauddin Makassar Program Studi Keperawatan Semester 4 Tahun Akademik 2020/2021 pada mata kuliah yang peneliti ampu yakni Keperawatan Medikal Bedah II (KMB II), materi sistem pencernakan. Hasil belajar mahasiswa, jumlah mahasiswa yang memenuhi nilai minimal sebanyak 34 Mahasisiwa $(53,97 \%)$. Berdasarkan hasil tersebut peneliti melakukan refleksi awal berupaya mengindentifikasi permasalahan perkuliahan pada pra siklus dan sehingga bisa dicarikan solusi yang efektif untuk meningkatkan aktivitas dan hasil belajar mahasiswa tersebut.

Adapun penyebab rendahnya aktivitas dan hasil belajar pada pra siklus adalah dosen menggunakan metode ceramah dan hanya menggunakan aplikasi tunggal yakni Zoom Cloud Meeting. Pada pembelajaran pra siklus ditemukan berbagai kendala yakni: 1) Boros kuota internet, sehingga sebagian mahasiswa tidak dapat mengikuti perkuliahan sampai tuntas; 2) tidak seluruh mahasiswa dapat mengakses Zoom Cloud Meeting dengan baik, karena kondisi geografis di kampung halaman sinyalnya tidak stabil sehingga dosen kesulitan mengontrol aktivitas pembelajaran mahasiswa.

Berdasarkan permasalahan tersebut peneliti melakukan inovasi pembelajaran dengan yang dapat meningkatkan aktivitas dan hasil belajar mahasiswa yakni menerapkan metode diskusi berbasis e-leaning dengan menggunakan 3 (tiga) aplikasi dalam proses pembelajaran dan penilaian yakni Edmodo, Zoom Cloud Meeting dan Quizizz. Metode diskusi dipilih karena metode ini memungkinkan mahasiswa berinteraksi aktif dengan mahasiswa lain maupun dengan dosen. Metode diskusi adalah suatu cara penyajian bahan pembelajaran dimana guru, dalam konteks ini dosen, memberi kesempatan kepada para siswa (kelompok-kelompok siswa) untuk mengadakan perbincangan ilmiah guna mengumpulkan pendapat, membuat kesimpulan atau menyusun berbagai alternatif pemecahan atas sesuatu masalah (Suharjo, 2010). Pembelajaran berbasis E-learning dengan menggunakan 3 (tiga) aplikasi Edmodo, Zoom Cloud Meeting dan Quizizz dimana masing-masing applikasi tersebut memiliki fungsi yang berbeda akan tetapi secara sinergis memungkinkan proses pembelajaran meningkat secara signifikan. Selain itu, pertimbangan penggunaan 3 (tiga) aplikasi tersebut adalah bahwa mahasiswa peneliti termasuk dalam generasi yang lahir diatas tahun 1995, sehingga bisa disebut sebagai generasi $\mathrm{Z}$ atau internet generation dan bisa juga disebut digital natives. Generasi manusia yang dikemukakan Jim Marteney (2010) yang dikutip Hasugian dalam Mardina R (2011) dibagi dalam 6 kategori yaitu: (a) the Greatest Generation (world war II, 1901-1924), (b) the Silent Generation (1925-1942); (c) the Baby Boomers (19431960); (d) Generasi X (1961-1981); (e) Millennial (1982-2002); (f) Digital Natives (Generasi Z atau Internet Generation), mulai tahun 1994 sampai akhir tahun 
sekarang. Generasi digital natives kadang disebut the native gadget yang lahir pada abad digital (Avarez, 2009; Brynko, 2009; Prensky, 2001).

Selain kebiasaan baru yang muncul dari generasi digital natives, Gaith (2010) mengemukakan bahwa gaya belajar juga bisa terpengaruh, sehingga muncul anggapan bahwa cara belajar mereka sudah terbiasa dengan serba cepat, menciptakan koneksi secara acak, memproses informasi visual secara dinamis dan bisa saja informasi yang diperoleh bisa akurat atau bermanfaat. Dengan demikian meskipun mahasiswa menggunakan beberapa aplikasi sekaligus dalam proses pembelajaran berbasis E-learning tidak ada kendala teknis yang signifikan.

Pada pra siklus peneliti menggunakan metode ceramah dan tanya jawab, akan tetapi dengan hanya menggunakan satu jenis aplikasi Zoom Cloud Meeting aktivitas belajar mahasiswa rendah. Dengan demikian dalam penelitian ini digunakan metode diskusi, dengan pertimbangan 3 (tiga) aplikasi tersebut, Edmodo, Zoom Cloud Meeting dan Quizizz dapat menujang keterlaksanaan metode diskusi secara efektif yang dapat meningkatkan aktivitas belajar mahasiswa. Berdasarkan latar belakang tersebut peneliti melaksanakan penelitian dengan judul "Penerpan Metode Diskusi Berbasis E-learning dengan Penggunaan Aplikasi Edmodo, Zoom Cloud Meeting dan Quizizz Untuk Meningkatkan Aktivitas dan Hasil Belajar Mahasiswa Materi Sistem Pencernakan Pada Program Studi Keperawatan UIN Alauddin Makassar Semester 4 Tahun Akademik 2020/2021". Judul tersebut diangkat untuk mengetahui peningkatan hasil belajar mahasisiwa.

\section{METODE PENELITIAN}

\section{Penelitian Tindakan Kelas}

Menurut Suharsimi Arikunto (2010) penelitian tindakan kelas merupakan kegiatan penelitian yang dilakukan terhadap sejumlah subjek yang menjadi sasaran yaitu peserta didik, bertujuan memperbaiki situasi pembelajaran di kelas agar terjadi peningkatkan kualitas pembelajaran. Penelitian tindakan kelas (PTK) dilaksanakan sebagai strategi pemecahan masalah dengan memanfaatkan tindakan nyata di lapangan kemudian melakukan refleksi terhadap apa yang telah dilakukan dan hasil tindakan. Penelitian tindakan sesuai sebagai upaya meningkatkan kualitas subyek yang diteliti. Penelitian Tindakan Kelas ini dilaksanakan untuk meningkatkan aktivitas belajar dan hasil belajar dengan Penerpan Metode Diskusi Berbasis Elearning dengan menggunakan aplikasi Edmodo, Zoom Cloud Meeting dan Quizizz materi sistem pencernakan pada Program Studi Keperawatan UIN Alauddin Makassar Semester 4 Tahun Akademik 2020/2021.

\section{Desain penelitian}

Penelitian ini merupakan bentuk penelitian tindakan kelas (classroom action research) yang dilaksanakan sebagai strategi pemecahan masalah. Pada penelitian tindakan dibagi menjadi 3 tahapan yaitu perencanaan (planning), tindakan (action) dan observasi (observe), serta refleksi (reflect) Model penelitian tindakan kelas yang akan digunakan dalam penelitian ini adalah menggunakan model (Kemmis dan Mc Taggart, 1988).

\section{Setting Penelitian dan karakteristik Subjek Penelitian.}

Tempat penelitian ini dilaksanakan di UIN Alauddin Makassar, khususnya pada mahasiwa Semester 4 Program Studi Ilmu Keperawatan Mata Kuliah 
Keperawatan Medical Bedah II materi sistem pencernakan. Pemilihan lokasi teersebut karena tempat peneliti melakukan aktvitas dan tugas mengajar memberikan kuliah, sehingga memenuhi kriteria lokasi Penelitian Tindakan Kelas.

Penelitian ini dilaksanakan khusus pada Semester 4 Tahun Akademik 2020/2021. Penelitian dilakukan dua siklus Siklus PTK, Penelitian ini dilaksanakan dalam 2 siklus, pada setiap siklus dilaksanakan mengikuti prosedur yaitu perencanaan, pelaksanaan tindakan, observasi dan refleksi. Melalui dua siklus tersebut dapat diamati peningkatan aktivitas belajar dan hasi belajar mahasiswa dengan penerapan metode diskusi berbasis e-learning menggunakan aplikasi Zoom Cloud Meeting, Edmodo dan Quizizz.

Subjek penelitian adalah mahasiswa UIN Alauddin Makassar, khususnya pada mahasiwa Semester 4 Program Studi Ilmu Keperawatan, sebanyak 63 mahasisiwa yang terdiri dari 11 laki-laki dan 52 perempuan. Mata kuliah yang mata kuliah Keperawatan Medikal Bedah II pada materi sistem pencernakan.

Adapun variabel-variabel yang diselidiki dalam pelaksanaan penelitian tindakan kelas ini adalah sebagai berikut : a) Variabel input: Mahahasiswa UIN Alauddin Makassar Program Studi Ilmu Keperawatan Semester 4 Tahun Akademik 2020/2021; b) Varibel proses: penerapkan metode diskusi berbasis e-learning dengan menggunakan aplikasi zoom meting, admodo dan quisy; variable output meningkatkan aktivitas dan hasil belajar mahasiswa.

Sesuai dengan rancangan penelitian dimana peneliti menggunkanan 3 tahapan yaitu perencanaan (planning), tindakan (action) dan observasi (observe), serta refleksi (reflect). Diawali dengan tindakan pendahuluan yakni melakukan refleksi awa pra siklus dimana ditemukan data bahwa aktivitas dan hasil belajar mahasisiwa rendah, dilanjutkan dengan pelaksanaan siklus. Dalam pelaksanaan penelitian ini langkah awal adalah perencanaan yang meliputi menyusun SAP dengan penerapan metode diskusi berbasis e-learning dengan menggunakan aplikasi zoom meeting, admodo dan quisi sebagai tindakan perbaikan pada pembelajaran sitem pencernakan. Selain itu penelti juga menyusun pedoman observasi dan alat evaluasi dalam aplikasi quisy. Dilanjutkan dengan tindakan berdasarkan SAP yang telah disusun. Selama proses pelaksanaan tindakan dilakukan pengamatan (Observasi) yang melibatkan beberapa pihak diantaranya, peneliti, dan dosen sejawat dengan berpedoman pada lembar observasi yang telah disusun dan disiapkan oleh peneliti. Observer melakukan pengamatan terhadap aktivitas mahasiswa selama berlangsungnya proses pembelajaran. Selanjutnya dilakukan analisis hasil observasi untuk mengetahui keaktifan mahasisiwa, dosen dan hasil belajarnya. Tahapan selanjutnya adalah refleksi. Keseluruhan hasil pengamatan, observasi, evaluasi mahasiswa, dan jurnal berupa catatan selama penelitian dianalisis, dijelaskan, dan disimpulkan pada tahap refleksi. Refleksi bertujuan untuk mengetahui keberhasilan dari proses pembelajaran sistem pencernakan dengan menerapkan metode diskusi berbasis e-learning dengan menggunakan aplikasi zoom meting, admodo dan quisy;

Peneliti bersama observer menganalisis hasil tindakan siklus I dan II untuk menentukan prlu tidaknya dilakukan siklus lanjutan. Penelitian Tindakan Kelas ini dilakukan 2 siklus. Hasil refleksi dan evaluasi siklus I masih tuntas, sehingga dilakukan perbaikan pada siklus II. Siklus II merupakan tindakan perbaikan dari hasil reflleksi pada siklus I yang dinyatakan belum berhasil. Langkah-langkah dan tahapan 
pada siklus II pada dasrnya sama dengan penerapan pembelajaran pada siklus I dengan mengacu ada SAP perbaikan siiklus II sebagai hasil refleksi siklus I.

\section{Data dan Cara Pengumpulannya}

Pelaksanaan Penelitian Tindakan Kelas ini data yang diperoleh ada 2 (dua) jenis yakni data kualitatif dan data kuantitatif.

Sumber data diperoleh dari mahasiwa Semester 4 program studi Pendidikan Keperawatan Tahun Akademik 2020/2021 UIN Alauddin Makassar untuk mengetahui seberapa besar peningkatan aktivias dan hasil belajar setelah menerapkan metode diskusi berbasis e-learning dengan menggunakan aplikasi zoom meting, admodo dan quisy.

Teknik pengumpulan data yang digunakan dalam penelitian ini adalah observasi, tes, wawancara dan catatan lapangan.

\section{Teknik Analisis Data}

Analisis data guna menarik kesimpulan dari seluruh data yang telah diperoleh. Data yang dianalasis dari hasil observasi aktivitas mahasiswa dan dosen, hasil wawancara, catatan lapangan, serta hasil evaluasi mahasiswa. Data hasil observasi aktivitas dosen, hasil wawancara, dan hasil catatan lapangan dianalisis berupa deskripsi dalam bentuk penarikan kesimpulan. Data hasil penilaian mahasiswa dan hasil observasi aktivitas mahasiswa dianalisis dengan angka-angka. Kriteria ketuntasan belajar individu mahasiswa mencapai mahasisiwa mencapai nilai minimal 66 atau C. Kriteria ketuntasan belajar klasikal apabila 100\% mahasiswa telah mencapai nilai minimal 66 atau C. Untuk menganalisis ketuntasan belajar mahasiswa secara klasikal digunakan rumus:

Analisis ketuntasan belajar klasikal digunakan rumus:

Keterangan :

$$
N P=\frac{R}{S N} X 100
$$

$\mathrm{NP}=$ nilai persentase

$\mathrm{R} \quad=$ jumlah mahasiswa yang memperoleh nilai $\geq 66$

$\mathrm{SN} \quad=$ jumlah seluruh mahasiswa

\section{Instrumen Penelitian}

Instrumen penelitian yang digunakan ada dua jenis, yaitu:

1) Instrumen pengumpul data, meliputi lembar observasi, pedoman wawancara, lembar catatan lapangan, aplikasi quisy tes mahasiswa;

2) Instrumen pemandu analisis, meliputi tabel penskoran tes hasil belajar sistem pencernakan, lembar ketuntasan, dan kriteria keaktifan mahasiswa.

\section{Indikator Kinerja}

Indikator kinerja merupakan suatu kriteria yang digunakan untuk melihat tingkat keberhasilan dari kegiatan penelitian tindakan kelas dalam meningkatkan atau memperbaiki proses belajar mengajar dikelas. berikut:

Indikator kinerjanya untuk mengukur keeberhasilan PTK ini adalah sebagai

1) Nilai ketuntasan individual apabila mahasiswa mencapai angka minimal 66 atau C.

2) Ketuntasan hasil belajar apabila seluruh mahasiswa (100\%) mendapat nilai minimal 66 atau $\mathrm{C}$. 


\section{HASIL DAN PEMBAHASAN}

Penelitian Tindakan Kelas penerapan metode diskusi berbasis e-learning dengan penggunaan aplikasi Zoom Cloud Meeting, Edmodo dan Quizizz. Penelitian ini dilaksanakan dua siklus. Tujuan untuk mengukur tingkat peningkatan aktivitas dan hasil belajar pada ranah kogmniitif mahasiswa. Kondisi pra siklus hasil belajar mahasiswa pada post tes mahasiswa materi sistem pencernakan Pada Program Studi Keperawatan UIN Alauddin Makassar Semester 4 Tahun Akademik 2020/2021 mahasiswa tuntas dengan nilai minimal 66 atau nilai $\mathrm{C}$ sebnyak $36(57,14 \%)$ sedangkan yang tidak tuntas 27 (42,86\%) dari jumlah 63 mahasiswa subyek penelitian. Dari hasil refleksi peneliti pada hasil belajar pada pembelajaran pra siklus peneliti berkoolaborasi dengan dosen sejawat untuk merencanakan perbaikan tindakan pembelajaran yang dilakukan pada siklus I. Nilai hasil belajar pada pra siklus dapat dilihat pada Tabel 1 .

Tabel 1. Distribusi Frekuensi Pra siklus Nilai Mata Kuliah Medikal Bedah II, materi sistem pencernakan

\begin{tabular}{l|l|l|l}
\hline \multicolumn{4}{l}{ Pra siklus } \\
\hline No. & Nilai/Hasil Belajar & \multicolumn{2}{l}{$\begin{array}{l}\text { Jumlah } \\
\text { Mahasiswa }\end{array}$} \\
\hline 1 & Tuntas & 36 & 57,14 \\
\hline 2 & Tidak Tuntas & 27 & 42,86 \\
\hline
\end{tabular}

Berdasarkan hasil belajar mahasiswa pada kondisi pra siklus peneliti dan dosen sejawat merancang perencanaan untuk proses pelaksanaaan tindakan perbaikan pembelajaran pada siklus I. Setelah dilakukan tindakan siklus pada I terjadi kenaikan tingkat ketuntasan belajar mahasiswa. Pada tindakan siklus I mahasiswa yang tuntas berjumlah 48 mahasiswa atau $(76,19 \%)$ sedangkan mahasiswa yang belum tuntas 15 mahasiswa atau (24,41\%). Hasil tindakan siklus I dapat diihat pada Tabel 2.

Tabel 2. Distribusi Frekuensi Siklus I Nilai Mata Kuliah Medikal Bedah II, materi sistem pencernakan

\begin{tabular}{llll}
\hline \multicolumn{2}{l}{ Siklus I } & \multicolumn{2}{l}{ Persentase } \\
\hline No. & Nilai/Hasil Belajar & $\begin{array}{l}\text { Jumlah } \\
\text { Mahasiswa }\end{array}$ & \\
\hline 1 & Tuntas & 48 & 76,19 \\
\hline 2 & Tidak Tuntas & 15 & 23,81 \\
\hline
\end{tabular}

Berdasarkan data hasil penelitian kondisi pra siklus dan tindakan perbaikan pembelajaran siklus I dapat disajikan dalam Tabel 3, berikut:

Tabel 3. Perbandingan Distribusi Frekuensi Pra siklus dan Siklus I Nilai Mata Kuliah Medikal Bedah II, materi sistem pencernakan

\begin{tabular}{llllll}
\hline & & $\mathrm{t}$ & \multicolumn{3}{l}{ Siklus I } \\
\hline No. & $\begin{array}{l}\text { Nilai/Hasil } \\
\text { Belajar }\end{array}$ & $\begin{array}{l}\text { Jumlah } \\
\text { Mahasiswa }\end{array}$ & Persentase & $\begin{array}{l}\text { Jumlah } \\
\text { Mahasiswa }\end{array}$ & Persentase \\
\hline 1 & Tuntas & 36 & 57,14 & 48 & 76,19 \\
\hline 2 & $\begin{array}{l}\text { Tidak } \\
\text { Tuntas }\end{array}$ & 27 & 42,86 & 15 & 23,81 \\
\hline
\end{tabular}


Berdasarkan Tabel 3 dapat ditarik kesimpulan bahwa terdapat kenaikan tingkat ketuntasan belajar mahasiswa, dimana kondisi pra siklus tingkat ketuntasan belajar mahasiswa 36 mahasiswa atau $(57,14 \%)$ pada siklus I tingkat ketuntasan belajar mahasiswa mencapai 48 mahasiswa atau $(76,19 \%)$. Dengan demikian dapat disimpulkan terjadi peningkatan tingkat ketuntasan belajar mahasiswa 12 mahasiswa atau $(19,05 \%)$, dan tingkat ketidak tuntasan mahasiswa menurun sebesar 12 mahasiswa (19,05\%) dari keseluruhan mahasiswa yang berjumlah 63 mahasiswa.

Dari data tersebut tindakan perbaikan pembelajaran pada siklus I terdapat kenaikan tingkat ketutasan hasil belajar mahasiswa yang signifikan akan tetapi capaian tersebut belum mencapai indikator kinerja yang ditetapkan yakni Nilai ketuntasan individual apabila mahasiswa mencapai angka minimutal 66 atau dengan ketuntasan hasil belajar apabila seluruh mahasiswa (100\%) mendapat nilai minimal 66 atau C. Hasil refleksi pelaksanaan pembelajaran siklus I terdapat catatan-catatan penting yakni dosen telah merancang SAP dengan baik, sesuai dengan langkahlangkah penerapan metode diskusi berbasis e-learning dengan penggunaan aplikasi Zoom Cloud Meeting, Edmodo dan Quizizz. Permasalahan pembelajaran pada siklus I dapat diidentifikasi sebagai berikut: 1) Pada langkah awal penggunaan Zoom claud meeting dosen telah memeriksa kehadidran, kontrak waktu, menanyakan kesiapan mahasiswa, menjelaskan aturan perkuliahan akan tetapi belum secara menyeluruh memastikan seluruh mahasiswa benar-benar memahaminya sehingga terdapat mahasiswa yang belum jelas alur tugas yang akan dilakukan mahasiswa. 2) Pada penggunaan aplikasi Edmodo dalam kerja kelompok masih terdapat anggota kelompok yang dalam menyelesaikan tugasnya didominasi oleh beberapa anggota kelompok tertentu sehingga terapat anggota kelompok yang pasif dalam berdiskusi dan menyelesaikan tugas dengan aplikasi Edmodo, dosen belum optimal dalam mengaktifkan mahasiswa. 3) Pada pelaksanaan pos tes, penilaian dengan menggunakan aplikasi Quizizz terdapat mahasiswa yang lamban dalam mengerjakan tugas dikarenakan belum seluruh mahasiswa memiliki strategi dan teknik mengerjakan pilihan ganda soal analisis kasus dengan cepat dan tepat. Berdasarkan hasil refleski siklus I maka pelaksanaan perbaikan pembelajaran peru dilanjutkan ke siklus II.

Dari hasil refleksi siklus I, maka dilaksanakan proses perbaikan pembelajaran siklus II dengan memperhatikan temuan-temuan di siklus I khususnya yang menjadi kendala keberhasilan siklus I. Pada pelaksanaan perbaikan pembelajaran siklus II, dosen telah berhasil memperbaiki langkah awal penggunaan Zoom claud meeting dengan secara menyeluruh memastikan seluruh mahasiswa benar-benar memahaminya sehingga terdapat mahasiswa yang belum jelas alur tugas yang akan dilakukan mahasiswa. Demikian pula pada penggunaan aplikasi Edmodo dalam kerja kelompok seluruh anggota kelompok tertentu tidak lagi mendominasi sehingga anggota kelompok yang sebelumnya pasif sudah aktif dalam berdiskusi dan menyelesaikan tugas dengan aplikasi Edmodo.Pada pelaksanaan pos tes, penilaian dengan menggunakan aplikasi Quizizz dosen telah membekali mahasiwa dengan strategi dan teknik mengerjakan pilihan ganda soal analisis kasus dengan cepat dan tepat, sehingga mahasiswa tidak lagi mengalami hambatan signifikan dalam mengerjakan pos tes menggunakan aplikasi Quizizz, bahkan mahaiswa yang kompetensinya tinggi pos tes tes menggunakan aplikasi Quizizz dirasakan sebagai tes yang menantang dan menyenangkan (enjoyable test). 
Dengan langkah perbaikan pembelajaran pada tindakan siklus II tingkat ketuntasan mahasiswa meningkat dibandingkan dengan siklus I. Pada tindakan siklus II mahasiswa yang tuntas berjumlah 63 mahasiswa atau (100\%) sedangkan mahasiswa yang belum tuntas tidak ada atau (\%). Tindakan perbaikan pembelajaran siklus II dapat disajikan dalam Tabel 4.

Tabel 4. Distribusi Frekuensi Siklus II Nilai Mata Kuliah Medikal Bedah II, Materi Sistem Pencernakan

\begin{tabular}{llll}
\hline & & Siklus I & \\
\hline No. & Nilai/Hasil Belajar & $\begin{array}{l}\text { Jumlah } \\
\text { Mahasiswa }\end{array}$ & Persentase \\
\hline 1 & Tuntas & 63 & 100 \\
\hline 2 & Tidak Tuntas & 0 & 0 \\
\hline
\end{tabular}

Hasil tindakan siklus I dan II dapat disajikan dalam bentuk Tabel 5 sebagai berikut:

Tabel 5. Perbandingan Distribusi Frekwensi Nilai Mata Kuliah Medikal Bedah II, materi sistem pencernakan Siklus I dan Siklus II

\begin{tabular}{llllll}
\hline & & Siklus I & \multicolumn{3}{c}{ Siklus II } \\
\hline No. & $\begin{array}{l}\text { Nilai/Hasil } \\
\text { Belajar }\end{array}$ & $\begin{array}{l}\text { Jumlah } \\
\text { Mahasiswa }\end{array}$ & Persentase & $\begin{array}{l}\text { Jumlah } \\
\text { Mahasiswa }\end{array}$ & Persentase \\
\hline 1 & Tuntas & 48 & 76,19 & 63 & 100 \\
\hline 2 & $\begin{array}{l}\text { Tidak } \\
\text { Tuntas }\end{array}$ & 15 & 23,81 & 0 & 0 \\
\hline
\end{tabular}

Dari Tabel 5 data perbandingan distribusi frewensi hasil belajar siklus I dan siklus II dapat ditarik kesimpulan bahwa terdapat peningkatan ketuntasan hasil belajar mahasiswa dari tindakkan siklus II. Pada siklus I tingkat ketuntasan mahasiswa mencapai 48 mahasiswa atau $(76,19 \%)$ dan pada tindakkan pada siklus II tingkat ketuntasan mencapai 63 mahasiswa atau (100\%). Dengan demikian terjadi kenaikan hasil belajar mahasiswa sebanyak 15 mahasiswa atau $(20,58 \%)$ dan tingkat ketidak tuntasan mahasiswa menurun sebesar 7 mahasiswa atau $(23,81 \%)$. Dari hasil tindakkan perbaikan pembelajaran siklus II permasalahan, kendala yang teridentifikasi pada siklus I dapat teratasi dengan baik sehingga ketuntasan belajar mahasiswa meningkat pada siklus II. Pembelajaran pada siklus II telah mencapai indikator kinerja yang ditetapkan yakni Nilai ketuntasan individual apabila mahasiswa mencapai angka minimutal 66 atau dengan ketuntasan hasil belajar apabila seluruh mahasiswa (100\%) mendapat nilai minimal 66 atau C. Dengan hasil tersebut maka pelaksanaan perbaikan pembelajaran siklus II melaui penerapan metode diskusi berbasis e-learning dengan penggunaan aplikasi Zoom Cloud Meeting, Edmodo dan Quizizz dinyatakan berhasil dan tidak perlu dilanjutkan pada siiklus berikutnya.

\section{KESIMPULAN}

Penerpan metode diskusi berbasis E-learning dengan penggunaan aplikasi Zoom Cloud Meeting, Edmodo dan Quizizz dapat meningkatkan hasil belajar mahasiswa materi sistem pencernakan pada Program Studi Keperawatan UIN Alauddin Makassar Semester 4 Tahun Akademik 2020/2021. Ketuntasan hasil 
belajar pada pra siklus 36 mahasiswa atau $(57,14 \%)$ pada siklus I mencapai 48 mahasiswa atau $(76,19 \%)$ mengalami peniingkatan 12 mahasiswa atau $(19,05 \%)$, dan tingkat ketidak tuntasan belajar mahasiswa menurun sebesar 12 mahasiswa $(19,05 \%)$ dari keseluruhan mahasiswa yang berjumlah 63mahasiswa. Siklus II tingkat ketuntasan mencapai 63 mahasiswa atau (100\%) terjadi peningkatan hasil belajar mahasiswa sebanyak 15 mahasiswa atau (20,58\%) dan tingkat ketidak tuntasan mahasiswa menurun sebesar 7 mahasiswa atau $(23,81 \%)$.

\section{SARAN}

Penelitian untuk mengembangkan metode pembelajaran khususnya dibidang keperawatan masih sangat luas terutama yang bekaitan dengan aplikasi yang digunakan sebagai media pembelajaran selama masa pembelajaran online.

\section{DAFTAR PUSTAKA}

Arikunto, S (2010), Penelitian Tindakan Kelas, Jakarta: PT Bumi Aksara.

Basori. (2013). Pemanfaatan Social Learning Network "Edmodo" dalam Membantu Perkuliahan Teori Bodi Otomotif di Prodi PTM JPTK FKIP UNS. JIPTEK., VI(2).

Dimyati dan Mudjiono. (2006). Belajar dan Pembelajaran. Jakarta: Rineka Cipta.

Kemmis, S. \& Taggart, R. (1988). The Action Research Planner. Victoria: Deakin University Press.

Kunandar, Langkah Mudah Penelitian Tindakan Kelas sebagai Pengembangan Profesi Dosen, ( Jakarta : Rajawali Pers, 2008 ), h. 127.

Mardina, R. (1) "Potensi Digital Natives Dalam Representasi Literasi Informasi Multimedia Berbasis Web Di Perguruan Tinggi”, Jurnal Pustakawan Indonesia, 11(1). Available at: http://journal.ipb.ac.id/index.php/jpi/article/view/5264 (Accessed: 2November2020)

Moedjiono \& Moh. Dimyati. 1991/1992. Strategi Belajar Mengajar. Jakarta : Departemen Pendidikan dan Kebudayaan Dirjen Pendidikan Tinggi Proyek Pembinaan Tenaga Kependidikan.

Mei, S. Y., Ju, S. Y., \& Adam, Z. (2018). Implementing Quizizz as Game Based Learning in the Arabic Classroom. European Journal of Social Sciences Education and Research, 12(1), 208.

Nana Sudjana. (2009). Penilaian Hasil Proses Belajar Mengajar. Bandung: PT. Remaja Rosdakarya.

Purba, L. S. L. (2019). Peningkatan Konsentrasi Belajar Mahasiswa Melalui Pemanfaatan Evaluasi.

Roestiyah. 2008. Strategi Belajar Mengajar. Jakarta : Rineka Cipta.

Sagala, Syaiful. 2003. Konsep dan Makna Pembelajaran. Bandung : Alfabeta

Suharjo. 2010. Belajar dan Pembelajaran. Malang : Fakultas Ilmu Pendidikan Universitaas Negeri Malang. 
Sanjaya, Wina. 2011. Strategi Pembelajaran Berorientasi Standar Proses Pendidikan. Jakarta: Kencana.

Suriadhi, G. (2014). Pengembangan E-learning Berbasis Edmodo pada Mata Pelajaran IPA Kelas VIII di SMPN 2 Singaraja. Journal Edutech, 2(1).

Thiyagu, K., \& Muthuchamy, I. (2011). Technology and teaching. India: Kalpaz.

Wibawanto, T. (2020). Pemanfaatan Video Conference Dalam Pembelajaran Tatap Muka Jarak Jauh Dalam Rangka Belajar Dari Rumah.

Wijayanto, E. (2017). Pengaruh Penggunaan Media Game Edukasi Terhadap Hasil Belajar IPA Siswa Kelas IV SDN Kajartengguli Prambon Sidoarjo. Jurnal Penelitian Pendidikan Guru Sekolah Dasar, 5(3). 